\title{
Transformation of the structure professions in higher agricultural schools of Siberia at the end of 1950-s - beginning of 1990-s
}

\author{
Valeriy V. Petrik ${ }^{1, a}$, Sergey F. Fominyh ${ }^{2}$, and Aleksey S. Surmillo ${ }^{1}$ \\ ${ }^{1}$ Tomsk polytechnic university, 634050 Lenina str., 30, Tomsk, Russia \\ ${ }^{2}$ Tomsk state university, 634050 Lenina str., 36, Tomsk, Russia
}

\begin{abstract}
The article reveals the transformations happened to the specialties structure in Higher agricultural education of Siberia at the end of the 1950s-the beginning of the 1990s. On the basis of archive documents there were analyzed the measures taken by central administrative structures, local authorities and the academic staff of the region for further development and perfection of major organization departments in eight agricultural institutes and their branches. It is stated that to the end of the period reviewed the number of faculties and specialties in Siberian agricultural higher educational institutions rose two times in comparison with the beginning of the period. Some of the agricultural institutes and their branches showed the rise in three or four times. In consequence of the measures they raised the number of specialists trained in Agronomics, Livestock engineering, Mechanics, Power engineering, Veterinary, Economics, for rapidly developing branches of regional agriculture. The article is intended to people interested in history of Higher education in Russia.
\end{abstract}

\section{Introduction}

Higher agricultural education is an integral part of the system of Higher education in Russia. Training a highly skilled specialist in agro industrial complex, transmitting to a totally new quality level contributes to strengthening the food supply security of the country and rising the living standards and quality of life of rural sector. The issue of human resources in agro industrial complex has a great socio economic value. It has been and will remain one of the state policy priorities.

In this regard the interest to the history of higher agricultural school in the country and in the region, especially in the period from the late 1950s' till the early 1990s', has risen significantly. The history of higher agricultural education in Siberia is not an exception. In the period mentioned above there existed eight higher educational establishments and their branches. Their structure had been dynamically developing and improving. Studying the traditions of higher schools of Soviet period makes it possible to understand the modern processes in the field of education.

\section{Materials and methods}

The reference base has been formed from the documents of the funds archive establishments of Siberia. These documents helped to reveal the practical work of the central and regional authorities and governments, administration and public organizations of higher educational establishments aimed at the development and perfection of the basic structural divisions of Higher agricultural school at the given period.

A lot of research is devoted to the development of Russian (Soviet) higher school of the XX the beginning of XXI centuries. Among them there should be mentioned the works of Anglo-American researchers (V. Prut, O. Anweiler, H. Balzer) who characterized the basis for the organization of educational activities in the USSR, analyzed the problems of soviet higher education of $1950 \mathrm{~s}$-the beginning of $1990 \mathrm{~s}$ [ $1,2,3]$. The modern condition of Higher school in Russia and the processes of its globalization are studied by F. Maringe, N. Foskett, E. Schofer, J.Meyer, etc. [4, 5]. The problem of the functioning of Higher educational establishments in the regions, Siberia in particular, has not been studied well enough.

The research followed the principles of historic method, systemacity and objectivity that allowed to view the historical processes in their development and interconnection, to analyze and assess facts comprehensively. There were used the problematic chronological, narrative and statistical methods.

\footnotetext{
a Corresponding author: v.v.petrik@mail.ru
} 


\section{Results and discussion}

The higher educational establishments training the specialists for agro-industrial complex rank high among the higher schools. In the period under review their structure underwent great changes. More than fifty agrarian higher schools trained human resources for rural sector in 1958/59 academic year. There counted up to 246 thousand students [6].

Altai, Buryat, Irkutsk, Krasnoyarsk, Omsk, Novosibirsk Agrarian High schools and Omsk Institute for Veterinary trained specialists for degrees [7].

Meanwhile, collective and state farms were underfurnished by agronomists, livestock specialists, mechanic engineers, economists and other specialists with higher education. In 1959, taking into consideration the numerous appeals of Tyumen regional committee of the Communist Party of Soviet Union and Council of National economy the USSR, Council of Ministers enacted a regulation: "Resolution on establishing of the Agricultural High school in Tyumen". The Higher educational establishment was opened comprising two faculties: the Agronomical Faculty and the Faculty of Zoo-veterinary with 125 students in 1959/60 academic year [8].

The administration of Tyumen Agricultural Institute (TAI) and the Rector Prof. A.Malov himself took measures for extension of specialty structure of the Institute in the 1960s the first half of the 1980s. To the existing two faculties there were added the Faculty of Accounting (Dean Prof. A.Shkuratov), the Faculty of Mechanic Engineering (Dean Prof.r M. Adrianov), the Faculty of Economics (Dean Prof. I. Kuzmina). There were also organized two departments: the Department of Agricultural production management and the Department of Labor Safety and Civil Defense [9].

The first Siberian agrarian higher educational establishment became Omsk Agricultural Institute (OAI), founded by the Siberian Soviet of workers and peasants' deputies on February 24, 1918.

Recently founded Omsk Agrarian Institute joined Omsk Agricultural Institute in 1922. Many other activities fostering the scientific work development and institute academic bases reinforcement were held at that time.

In March 1922 Omsk Agricultural Institute was reorganized into Siberian Agricultural Academy with four faculties: Agronomical, Forestry, Agrarian and Remedial school for workers.

In 1930s Omsk Agricultural Institute underwent a set of reorganizations that had a bad impact on its development. As a result, the Forestry faculty left the Institute and became the basis for the foundation of a new Forestry Engineering Institute that was later moved to Krasnoyarsk city. On the basis of the remaining three faculties and departments there were organized three new independent institutes. In three years they were again united into Siberian Institute of Agriculture. In 1935 the educational establishment was renamed into Omsk Agricultural Institute [10]. In the early 1960s, In Omsk Agricultural Institute (Director D.Tokarev) there counted four faculties, 46 departments; more than three thousand students were trained in 15 specialties and specializations [11].

During two decades of 1960-1980s there were created several new faculties: the Faculty of Economics (Dean Prof. V. Sumnar), the Faculty of Agricultural Engineering (Dean Prof. V. Roor), Agricultural chemistry and Soil sciences (Dean Prof. A. Soloviev), Milk and Dairy Engineering (Dean Prof. N. Matveev); they trained specialists in twelve majors. Among them there were highly promising specialties such as Applied geodesy, Horticulture and winegrowing, Plant Breeding and Genetics [12].

Created in the years of the first five-year plans and re-appeared on a petition of local authorities of BuryatMongol Autonomous Soviet Socialist Republic in 1944, Veterinary Institute enlarged. To the moment of its reestablishment there were two faculties. The Faculty of Agronomics was opened in 1952, and then there followed the Engineering and Engineer-construction faculties in 1954. Two Correspondence departments were organized in 1955-1959 at the Veterinary Faculty and the Faculty of Agronomics. According to the Decree of Ministry of Agriculture of the Russian Soviet Federated Socialist Republic March 25, 1960, Buryat Veterinary Institute was reorganized into Buryat Agricultural Institute. At the beginning of 1960s there were five faculties that trained specialists in five majors [13]. In 1960, administration of Buryat Agricultural Institute with its Rector Professor N. Burnashev strove for allowance from the Ministry of Agriculture of the Union of Soviet Socialist Republics to open The Faculty of Economics (Dean Prof. A. Dulganov) with two departments where students could receive the qualification of Economist-facilitator and Accounting economist. The Faculty of Agricultural Engineering was created in 1961 (Dean Prof. A. Silaev); in 1962 the department of Agricultural Chemistry and Soil Sciences appeared within The Faculty of Agricultural Engineering, and in 1963 there were founded the Correspondence departments in Economics and Agricultural Engineering. From the middle of 1960s the Faculty of Advanced training for executive staff and specialists in agriculture started its work in eight majors [14].

Significant work in enhancing and developing the structure of the specialties was done in Novosibirsk Agricultural Institute (NAI) founded in 1938. If at the early 1960s there were four faculties at NAI - the Agronomic Faculty (founded in 1936), Veterinary (1936), Agricultural Engineering (1944), the Faculty Economics (1960) [15], then, in the following years, that coincided with difficult and turbulent years of country life, the Institute continued competitive enhancement.

An important event for Novosibirsk Agricultural Institute was the creation of the Faculty of Plant Protection in 1963 that started to train agriculturists in different fields. Since that time up to 1968 specialists in this field had been trained at the Agronomic Faculty with the Department of Plant Protection at Agronomic Faculty. Then it was reorganized into the department of 
Phytopathology and the department of Entomology. The Faculty of Plant Protection became an independent unite of the Institute, its founders being the Dean of the Agronomic faculty Professor I. Leonov and Associate Professors L. Gusygina and L. Lebedeva. The faculty was the only one in Siberia and the Far East [16].

The year 1966 became for Novosibirsk Agricultural Institute the year of foundation of the Faculty of Advanced training for executive staff of collective farms, state farms and specialists in agriculture. Annually there were trained from 700 to 1000 people. The faculty served generally the needs of Novosibirsk, Kemerovo and Tomsk regions, and it was run by Vice-rectors P. Matyushin, V. Ignatiev, A. Konev, V. Medvedchikov [17].

The new department of the given agricultural higher education establishments in the system of advanced training began to appear in the second half of the 1980s. Here was established the Faculty of Advanced training for the academic staff (Dean Prof. V. Tokarev) in 1988, and later, in 1989 they founded one year Correspondence faculty of advanced training in Economics and then the Academic exchange English course for the specialists of agro industrial complex. The Department of Economic problems and Agro industrial management appeared in 1987. Since 1990 the farmers have been trained at night classes.

In 1966-1970 Novosibirsk Agricultural Institute opened Pre-training division, The Division of Economic cybernetics, and six new departments: the Theory of mechanisms and machinery, the Harvesting machinery, the Economic cybernetics, the Labor safety and etc. Alongside, there were formed laboratories: the Laboratory of Mathematical method, the Interfaculty analytical laboratory, Physiological stockyard. To the end of 1970 the students of full-time department, numbered 3250, and the Correspondence department counted 2750 students [18].

The important role in the structure of the agrarian higher educational establishment belonged to the Faculty of Veterinary that was opened on the basis of two Departments: the Department of Veterinary and the Department of Zoo engineering in 1979. In 1982 the Veterinary faculty separated into independent division of the Institute with the Dean Associate professor V. Kislenko as the Head of the Division. The faculty embraced four Departments: the Department of Anatomy and Hysology, Epizootology and Microbiology, Pathoanatomy, Surgery and intra noncontagious diseases [19].

In November 1990 the Faculty of Humanities structurally combined the departments of Political history, Philosophy, Politology, Foreign languages, Physical education, department of public professions and museums of the Institute [20].

One of the leading agrarian institutes in Siberia was Irkutsk Agricultural Institute (IAI) founded on the basis of Pacific Institute of Agriculture. At first, the Institute was situated in Vladivostok, but then it was transferred to Blagoveshchensk and finally to Irkutsk [21]. To the beginning of 1960s Irkutsk Agricultural Institute incorporated four faculties: Agrarian (Dean Prof. A. Kazansky), Livestock engineering (Dean Prof. L. Gerasimov), Agricultural engineering (Dean Prof. Yu. Turutin) and the Faculty of Game management (Dean Prof. N. Sviridov). In the following twenty years there were organized new faculties such as the Faculty of Economics, Engineering, Electrification of agricultural sector where the staff was trained in nine specialties [22].

After numerous pleas of Chita city local authorities to the superior bodies there was created the Chita branch of Irkutsk Agricultural Institute with Irkutsk Agricultural Institute as the head organization. The Chita branch of Irkutsk Agricultural Institute started its work in 1979/1980 academic year with four faculties: Engineering, Agronomic, Zoo engineering and Economics [23].

Altai Agricultural Institute came into existence in March 1944 on the basis of Pushkin Agricultural Institute (Leningrad region) with two faculties training students in Agronomics and Zoo technology. The Faculty of Agricultural engineering was introduced in Altai Agricultural institute in 1950 and it became the basis for training in Arable farming engineering, Livestock engineering, Farm machinery repair [24].

By the order of Ministry of Higher and Secondary Vocational Education of Union Of Soviet Socialist Republics from November 13, 1947 there was opened the Correspondence department in Agronomics and Livestock engineering. The department was modified into the Department of Correspondence Studies. To the beginning of 1960s the Department of Correspondence Studies of Altai Agricultural institute had five studysupport centers in Gorno-Altaisk, Biysk, Kamen-On-Ob, Slavgorod. If at the end of 1950 s the Institute had only three faculties: Agronomics, Livestock engineering and Agricultural engineering, then the following two decades added three more faculties to the Institute. They were the Economics, Veterinary and Hydrotechnology faculties [25].

Founded in 1952, Krasnoyarsk Agricultural Institute grew fast and steadily. It had three faculties: the Agronomics Faculty, the Faculty of Livestock engineering and Mechanical engineering [26]. The fourth faculty - the Veterinary Faculty - was opened in 1968. Since 1966 there had been working the Faculty of Advanced training for agricultural staff. In the structure of Agricultural institute there also was the Educationalexperimental plot "Minderlinskoye" [27].

On the Bureau of Krasnoyarsk regional committee of Communist party of the Soviet Union there was raised the question of "Improving the training of specialists in Agriculture". While performing the bylaws of the local authorities there were opened three the most necessary in the region specialties: the Electrification of Agricultural sector, Economy and Management of Agriculture and Accounting. They were also the newest in the region. The Correspondence faculties in Electrification of Agricultural sector (50 students) and Economics (100 students) started their work. In 1990-1991 academic year more than six thousand students were trained in the Agricultural institute full-time and correspondently [28]. 
Krasnoyarsk Agricultural Institute became the head organization for the Tuva branch of Krasnoyarsk Agricultural Institute which was created on the regulation of Council of Ministers USSR on May 4, 1984 with Agronomic and Livestock engineering faculties in it [29].

Among the agrarian Siberian higher educational establishments, Omsk Veterinary Institute (OVI) was of key importance. It was created by the regulation of Siberian revolutionary committee on December, 22 1920. At the turn of the decades 1950-1960s the training of veterinary staff was held on 24 departments. The number of students at that time counted 1192 [30].

Further, the organization of Omsk Veterinary Institute underwent significant changes that resulted in the increasing of the number of departments, clinics and laboratory.

The leading departments in Omsk Veterinary Institute were the Department of Pharmacology, Anatomy of livestock animals, Physiology, Livestock feeding, Therapy, Hystology, Parasitology and Livestock. A great contribution to the development of the departments made the Heads of the departments: Professors M. Kirillov, V. Tsingovatov, D. Krinitsin, V. Yudichev, N. Korovin, P. Ilin, Associate professors P. Kostyaev, V. Maslakov. Together with the departments of Omsk Veterinary Institute the work was held in the following clinics: Therapeutic clinic, Surgery, Obstetric and gynecological clinic, Parasitological clinic, Contagious disease clinic and Propedeutic clinic. There was a drug-store, a public outpatient department, a practice farriery, a physiotherapeutic and an X-ray office.

To foster the management of academic and practical training of the students there were used the resources of eight branches of the institute in industries and the educational-experimental plot "Kamyshlovskoye" [31].

Thus, in the period under review, in Siberian region there was opened a new Agricultural Institute, three branches of the Institute, several faculties, departments and specialties.

\section{Conclusion}

At the end of 1950 - the beginning of 1990s there was the further development and improvement of higher agricultural education in Siberia. The organizational structure of the process of educational became more complex and varied. As the result of the direct help provided by central and local agencies of State power and administration there became possible to raise the number of specialists trained in Agronomics, Livestock engineering, Mechanics, Power engineering, Veterinary, Economics, etc for rapidly developing branches of regional agriculture.

\section{Acknowledgment}

The programme was realized and subsided within the framework of the Programme for enhancing Tomsk Polytechnic University's competitiveness. The results presented herein were obtained with the assistance from Russian Fond.

\section{References}

1. V. Prut. Higher education in the USSR. New world review (New York: E-Publishing Inc., 1980)

2. O. Anweiler. The reform of the Soviet educational system: Between modernization and ideological control. Gorbachev and soviet future. (London: Boulder, 1988)

3. H. Balzer, Technology in soc. 13, 4 (1991)

4. F. Maringe, N. Fosket. Globalization and internationalization in higher education: theoretical, strategic and management perspectives (London: Continuum, 2010)

5. E. Schofer, J. Meyer. American Sociological Reviev, 70 (2005)

6. Higher Education in the USSR. Statistics digest (Moscow: Glavlit, 1961)

7. Historical note. From: The State Archive of the Novosibirsk Region (SANR), Fund R-1487, Inventory 1, fol. 3-4 (1959)

8. Decree of the Council of Ministers of the USSR "Resolution on establishing of the Agricultural High school in Tyumen". From: Documentation Center of Recent history of Tyumen region (DCRH TR), Fund 124, Inventory 134, File 42, fol. 28-32 (1959)

9. Reference on the work of Tyumen Agricultural Institute in 1960s - the first half of 1980s. From: DCRH TR, Fund 124, Inventory 198, File 79, fol. 17-18 (1984)

10. A. Filin, Agricultural production of Siberia and the Far, 11 (1966)

11. Reference on the work of Omsk Agricultural Institute (1959). Documentation Center of Recent History of Omsk region (DCRH OR), Fund 4094, Inventory. 6, File 1, fol. 1.

12. Reference on the work of Omsk Agricultural Institute, 1960s - 1980s. From: DCRH OR, Fund 17, Inventory 130, File 256, fol. 3 (1985)

13. Reference on the work of Buryat Agricultural Institute. From: National Archives of the Republic of Buryatia (NARB), Fund P-13, Inventory 1, File 5767, fol. 209-210 (1960)

14. Reference on the work of Buryat Agricultural Institute. From: NARB, Fund R-474, Inventory 15, File 1357, fol. 7 (1965)

15. Reference on the work of Novosibirsk Agricultural Institute. From: SANR, Fund P-501, Inventory 1, File 69, fol.10 (1960)

16. Reference on the work of Novosibirsk Agricultural Institute. From: SANR, Fund P-4, Inventory 66, File 91, fol. 64-85 (1963)

17. Reference on the work of Novosibirsk Agricultural Institute. From: SANR, Fund P-4, Inventory 33, File 4077, fol.39 (1966)

18. A.S. Vostrikov, I.A. Moletotov. The Profile of Novosibirsk High school history. (Novosibirsk, 1994) 
19. Historical note. From: SANR, Fund R-1487, Inventory 1, fol.3 (1982)

20. Annual report on the work of Novosibirsk Agrarian Institute. From: The current archive of Novosibirsk Agricultural Institute, fol. 10 (1991)

21. Historical note. From: Documentation Center of Recent History of Irkutsk region (DCRH IR), Fund 127, Inventory 72, File 1, fol. 11-12 (1975)

22. Reference on the work of Irkutsk Agricultural Institute in 1960s - the beginning of 1990s. From: DCRH IR, Fund 127, Inventory 79, fol. 1 (1990)

23. Historical note. From: The State Archive of the Chita Region (SACR), Fund P-3, Inventory 36, fol.3 (1981)

24. The Preface to the inventory. From: Center Archive Fund of the Altai Territory (CAFAT), Fund R-181, Inventory 5, fol. 4 (1972)

25. Reference on the work of Altai Agricultural Institute in 1940s - the beginning of 1990s. From: CAFAT, Fund P-1, Inventory 106, File 297, fol. 35-36 (1990)

26. Decree of the Council of Ministers of the USSR, April 29, 1952 2. "About the foundation of Krasnoyarsk Agricultural Institute”. From: The State Archive of Krasnoyarsk Territory (SAKT), Fund R-2122, Inventory 1, fol.3 (1952)

27. Reference on the work of Krasnoyarsk Agricultural Institute. From: Archival repository and research center of Recent History of Krasnoyarsk Territory (ARRCRH KT), Fund 26, Inventory 27, File 32, fol. 6-7 (1968)

28. Reference on the work of Krasnoyarsk Agricultural Institute. From: ARRCRH KT, Fund 26, Inventory 16, File 28, fol.42-43 (1990)

29. Regulation of Council of Ministers USSR, May, 4 1984. "About the organization of the Tuva branch of Krasnoyarsk Agricultural Institute". From: Archive Center of Political and Non-governmental organizations of the central State Archive of the Republic of Tuva (ACPNOSF RT), Fund 2, Inventory 24, File 54, fol. 140-141 (1984)

30. Reference on the work of Omsk Veterinary Institute. From: DCRH OR, Fund 17, Inventory 139, File 150, fol. 36-37 (1960)

31. Reference on the work of Omsk Veterinary Institute, 1980 s - the beginning of 1990s. From: DCRH OR, Fund 17, Inventory 195, File 125, fol.19-20 (1990) 